\title{
Az egészségmegőrzés és egészségfejlesztés szerepe a családorvosok képzésében- és továbbképzésében - 25 éves a győri Alapellátási Szabadegyetem
}

\author{
The Role of Health Preservation and Health Promotion in the Education \\ and Training of General Practitioners. The Open University of Primary \\ Health Care in Győr is 25 Years Old
}

Szerző: $\quad$ Schmidt Péter ${ }^{a} \bowtie$, Konczosné Szombathelyi Márta ${ }^{b}$

a: Egyetemi Oktató Gyermekorvosi Rendelő, Győr, b: egyetemi docens, Széchenyi István Egyetem Györ

Beküldve: 2017.06.24.

doi: 10.24365/ef.v58i3.161

Kulcsszavak: praxisfinanszírozás, akkreditáció, prevenció, képzés és továbbképzés, költség/ haszonelemzés, indikátorok, egészségfejlesztés - egészségmegőrzés

Keywords: praxis financing, accreditation, prevention, training and further training, cost / benefit analysis, indicators, health promotion - health preservation

Az egészségügyi alapellátás reformja 1992. július 1jével kezdődött hazánkban, mely új háziorvosi vállalkozási formaként biztosította a szabad orvosválasztás rendszerét, felváltva a korábbi évtizedek merev, szigorúan egyes utcákhoz rendelt körzeti orvosi határait. A szabad orvosválasztás minőségi mutatók tekintetében is előrelépést jelentett, önállóságot biztosítva a családorvosoknak tevékenységük kiszélesítésére: kiemelten a praxisukba tartozó betegek gondozását, a felvilágosító munkát és a krónikus betegségben szenvedők rendszeres visszarendelését illetően. ${ }^{1,2}$

A reformot megelőző évben - 1991. szeptember 1. december 31. között - a családorvosok részére győri javaslatként - folyamatos és rendszeres továbbképzést kezdeményeztünk és szerveztünk Alapellátási Szabadegyetem néven, a kollégák részletes tájékoztatására, ami a felkészülést jelentette a családorvosi-vállalkozási formára. Ennek keretében a résztvevők megismerték:
- az egészségnevelési és egészségfejlesztési programok megvalósításának módjait,

- szakirányú képzésen a könyvelési szempontokat,

- a gazdasági- és közgazdasági alapelveket, a szakma legkiválóbb előadóinak prezentálásában,

- az akkor még gyermekcipőben járó informatikai rendszereket, amelyhez folyamatos és intenzív gyakorlati képzés kapcsolódott.

- Emellett kiemelt témaként szerepelt és állandóan visszatérő konzultációkat jelentett egyes demográfiai indikátorok elemzése (morbiditási és mortalitási mutatók, születéskor várható átlagos élettartam, csecsemőhalálozás és koraszülöttség adatai) nemzetközi összehasonlításban is. ${ }^{3,4}$

A változásokhoz kapcsolódóan folyamatos és rendszeres képzés keretében általában a hónap 3. szombatján, az Egészséges Nemzedékért Alapítvány által koordinálva szerveztük a tudományos szimpózium- 
sorozatot, melybe bekapcsolódott a Semmelweis Egyetem Családorvosi Tanszéke, később a Pécsi Tudományegyetem és a Szegedi Tudományegyetem ÁOK Családorvosi Intézete is. Fenti egyetemi oktató intézmények jelentős segítséget nyújtottak az akkreditáció, illetve a kreditpontok biztosításával.

A továbbképzések komoly előnye volt és maradt is, hogy a résztvevők ingyenesen látogathatták, látogathatják rendezvényeinket. Kiemelt együttmúködő szervezetnek bizonyult Győr városa, Győr-MosonSopron megye Önkormányzata, az ÁNTSZ Városi és Megyei Szervezete, később a Megyei Orvosi Kamara is. A kihelyezett üléseket leszámítva, a Győri Városháza patinás díszterme volt az események méltó helyszíne.

A rendezvényeket szemeszterenként öt, így tanévenként tíz alkalommal szerveztük/szervezzük meg. A családorvosokon kívül mind nagyobb számban vesznek részt kórházi orvosok, ÁNTSZ munkatársak, védőnők, Országos Egészségbiztosítási és mentálhigiénés szakemberek, nemcsak Győr-Moson-Sopron megyéből, hanem a térség öt - Vas, Zala, Veszprém, Komárom-Esztergom és Fejér - megyéjéből is. A résztvevők számára jelentős segítséget jelentett, hogy folyamatosan kiadványokat jelentettünk meg a továbbképzések anyagaiból, melyek közül az első az Önkormányzati Háziorvosi útmutató volt. ${ }^{5}$

Az Alapellátási Szabadegyetem iránt az elmúlt években folyamatosan mind nagyobb az érdeklődés. Rendezvényenként átlagosan 120-150 kolléga vesz részt.

Legfontosabb célunk volt: naprakész információk biztosítása a háziorvosok számára, illetve átadni azokat az ismereteket, melyeket egyetemi tanulmányaik során nem tanultak vagy nem tanulhattak, különösen vonatkozott ez a prevencióval kapcsolatos ismeretekre és a gondozási munkára. Az általános tájékoztatókon túl, a diagnosztika és terápia tárgyköre mellett, mind jobban előtérbe kerültek az egészségnevelés, egészségfejlesztés ismeretei, a káros szenvedélyek elleni küzdelem, az egészségügy gazdasági, közgazdasági, jogi és etikai kérdései, valamint - kihelyezett képzés során - a társadalombiztosítással foglalkozó továbbképzés sorozat. ${ }^{2,6,7,8} \mathrm{Az}$ informatikai ismeretek széles körú elterjedésével nem csak a kollégák, hanem a praxisban dolgozó munkatársak is aktív szerepet játszottak.
A képzési-továbbképzési rendszer tevékenységét illetően kiemelten fontos szerepet játszott, hogy 1998. december 31-ét követően kizárólag csak szakirányú szakképesítéssel dolgozhatnak a családorvosok a körzetükben. Ezért - a házi-orvostan szakvizsgán túlmenően - mind több kolléga szerezte meg második, illetve további tárgyból a szakvizsgáját. A korábban „körzeti orvos” elnevezés „családorvossá” történt változtatásával nemcsak a név módosult, de a családorvoslás szakmai tekintélye is jelentősen megnőtt, amit az elmúlt negyedszázad eredményei egyértelmúen igazolnak. ${ }^{8,9} \mathrm{~A}$ háziorvosok tevékenysége önállóbbá vált, felelősségük megnőtt: kiemelt érdekük a praxisukhoz tartozó betegek gyógyítása, gondozása és rehabilitációja. Rendelőjükben a krónikus betegek ellátása is minőségi változáson ment át: elsősorban a cukorbetegségben, asztmás-allergiás, valamint a pszichés-pszichoszomatikus betegségben szenvedő páciensekre vonatkozóan. Ezen túlmenően életmód-életvezetési modell is megvalósult a praxisokban. A "Szülők Akadémiája" keretében a prevencióval kapcsolatos felvilágosító, egészségnevelési-egészségmegőrzési továbbképző sorozattal egészült ki az Alapellátási Szabadegyetem, nemcsak szakembereknek, de laikusoknak is. A résztvevők főként a kötelező és ajánlott védőoltásokról, azok esetleges mellékhatásairól, a lázcsillapításról, az egészséges táplálkozásról valamint az utazással kapcsolatos felvilágosító intézkedésekről hallhattak. ${ }^{10}$ Kiemelt témaként szerepelt a dohányzás, az alkoholfogyasztás és a drog káros hatásait és a megelőzés módját ismertető továbbképzés is, ami ezen túlmenően, az egészséges táplálkozásra és a káros szenvedélyek elleni hatékony preventív intézkedésekre tért ki. $6,7,8$

A háziorvosok - előzetesen végzett, általunk szerkesztett kérdőíves felmérés eredményeit összefoglalva - igénylik ezt a képzési-továbbképzési rendszert. Megtisztelő számukra, hogy az Alapellátási Szabadegyetem keretében üléselnökként, illetve előadóként vehetnek részt, s a rendezvényeink során elsajátított ismeretek akár többhetes tankönyvből történő felkészülést helyettesíthetnek.

Az Alapellátási Szabadegyetem keretében a háziorvosok aktívan és folyamatosan kapcsolódtak be egyes alapellátásban folyó kutatómunkába, mely nemcsak helyi, hanem országos jelentőségű felmérésekben való munkát is jelentett, sőt nemzetközi kitekintést is kaphattak az eredményekről. ${ }^{4}$ 
A családorvosok átlag életkora sajnos egyre magasabb, utánpótlásuk is egyre komolyabb gondot jelent, ezért a jövő orvos-generációja számára elengedhetetlenül fontos a családorvosok mind nagyobb anyagi megbecsülése, mind a társadalomban korábban elfoglalt méltó helyének biztosítása. Ez azt is jelenti, hogy a családorvosok megérdemelt módon élhessék nyugdíjas éveiket, időben átadva szakmai tapasztalataikat utódjaik számára.

A házi orvoslásban végzett prevenciós munka eredményei is mind jobban érvényesültek. Az orvoshoz fordulási szokások, de a fekvőbeteg osztályokkal való kapcsolat is megváltozott. Számos esetben maguk a páciensek is igénylik az egészségmegőrzéssel és egészségneveléssel, szakmai felvilágosítással járó képzéseket. A Népegészségügyi Program egyes kiemelt indikátorait is (egészséges táplálkozás, stressz-mentes élet, rendszeres testmozgás) felhasználták a családorvosok mindennapi gyakorlati munkájukban. Különösen érezhető volt az a tendencia a pszichés-pszichoszomatikus betegségben szenvedők esetében.,11,12 A kórházi pszichiátriai osztályra, illetve szakrendelésekre való bejutás sokszor akadályokba ütközik, az előjegyzési rendszer, illetve a hosszú várólisták miatt. Ezért a kollégák nagy számban - részben az Alapellátási Szabadegyetemen szerzett tudásuk alapján, részben szakirányú pszichiátriai képzések eredményeképp - az ilyen betegségben szenvedő, főként szorongó, nehezen kezelhető betegeik esetében az alapkezeléseket saját hatáskörben is el tudják végezni. Komoly szakmai változást eredményezett a családorvosok számára, hogy az informatikai rendszer kiszélesedésével pácienseik szakrendeléseken, fekvőbeteg intézményekben történt vizsgálatainak eredményeiről (röntgen, labor vizsgálatok, ultrahang stb.) már a vizsgálatokat követő néhány órában értesülhetnek, mely megkönnyíti számunkra az egyes osztályokkal, szakrendelőkkel való gyors konzultációt is.

Előzetes költség/haszon-vizsgálatok során bizonyítást nyert, hogy a Győr-Moson-Sopron megyében kezdeményezett, országos modellként szolgáló háziorvosi képzés-továbbképzés milyen jelentős költségmegtakarítással járt a résztvevők számára. A korábbi évek elemzései azt mutatják, hogy a családorvosok számára az anyagi megtakarítások egyre jobban érzékelhetők napjainkban, hiszen a kongresszusok részvételi költségei (regisztrációs díj, szálláskölt- ség, útiköltség, étkezés stb.), hatványozottan emelkedtek. $^{2,6}$

Költség/haszonelemzés:

Az elmúlt negyedszázad során összesen 225 szakmai továbbképzésre került sor Alapellátási Szabadegyetem formájában. Az átlagos látogatottsági számokat alapul véve (120-150 fő/rendezvény, átlag 130 fő), a résztvevők száma az elmúlt 25 évben 29 250 fő (130 fő x 225 rendezvény).

Egy före számítva egy fővárosban tartandó továbbképzés átlagos költsége 19000 Ft/fő. A megtakarítás az elmúlt negyedszázadban 29250 fő x 19000 $\mathrm{Ft} /$ fö = 555750000 forint.

Az eddigi 225 rendezvény során az előadók száma 2 300 fő volt. A szakmai előadásokon a legváltozatosabb témakörök szerepeltek: kardiológia, neurológia, pszichiátria, diabetológia, endokrinológia, az egészségügy gazdasági és közgazdasági kérdései, az OEP által kihelyezett tanfolyamok, vakcinológia, fertőző betegségek és megelőzési lehetőségeik, klinikai táplálás jelentősége, intenzív terápiás ellátás, az oxyológia elméleti és gyakorlati alkalmazása a napi háziorvosi gyakorlatban, igazságügyi-orvostani szakértői előadások, az alapellátásban használt és alkalmazott indikátorok részletes elemzése.

Az elmúlt negyedszázad során együttmúködésünk a Győri Petz Aladár Megyei Oktató Kórházzal gyümölcsöző volt. Ennek bizonyítéka, hogy a Semmelweis Egyetem Családorvostani Tanszéke, illetve a Pécsi és a Szegedi Tudományegyetem Családorvosi Intézete által delegált szakmai előadók mellett a Győri Petz Aladár Megyei Oktató Kórház mind több kiváló munkatársa tartott nagy sikerrel előadást. Az oktató munkába bekapcsolódott a Széchenyi István Egyetem is, ahol kihelyezett ülést is tartottunk.

2012 óta minőségi megújulást jelentett az Alapellátási Szabadegyetem múködésében, hogy a Szegedi Tudományegyetem ÁOK Családorvosi- és Foglalkozás-egészségügyi Rendelő segítségével, dr. Mester Lajos c. egyetemi docens családorvossal közösen, évente 2 alkalommal, 50 kreditpontos, akkreditált, 3 napos, szinten tartó továbbképzést tarthatunk Győrben, a Szegedi Tudományegyetem kihelyezett képzéseként.

Nagyon fontosnak tartjuk a kiváló kezdeményezésű Alapellátás-fejlesztési Modellprogramot (Svájci Hozzájárulás keretében valósul meg), mely jelenleg is komoly szakmai sikereket biztosít egyes régiók 
alapellátási munkájának minőségi fejlesztésében. A Modellprogram eredményeiről az Alapellátási Szabadegyetem keretében is szeretnénk minél részletesebb tájékoztatást nyújtani. ${ }^{13}$

Abban, hogy továbbképzés sorozatunkat megindíthattuk, sikerrel megvalósíthattuk és folyamatosan megszervezhettük, hálás és elévülhetetlen köszönet illeti Simon Tamás professzor urat, professor emeritust, aki részben az Egészségnevelés c. szakfolyóiratban, illetve annak jogutódjában az Egészségfejlesztésben, valamint a Magyar Tudományos Akadémia Bizottságaiban folyamatosan ismertette a továbbképzéseinket, egyben rendszeres személyes jelenlétével garantálta a szakmai sikereket.

Az akkreditációt biztosító Semmelweis Egyetem ÁOK Családorvostani Tanszéke részéről dr. Tamás Ferenc és közvetlen munkatársa, Fekete Ilona együttmúködése meghatározó.

Ugyancsak hálás köszönettel tartozunk azon kollégáknak, akik az elmúlt 25 év során szinte állandó részevői voltak a továbbképzéseknek, akik komoly szakmai közösséget hoztak létre, és vitték a tudást a praxisukba. Kiváló szakmai munkájukkal, előadásaikkal, üléselnökségükkel, vitavezető szerepben, illetve konzultációk révén emelték a továbbképzés rangját.

Az alábbi kollégák a tudásmegosztást garantálva vitték körzetükbe továbboktatásra az egyes Alapellá- tási Szabadegyetemen elhangzottakat: Dr. Hidas János vértessomlói háziorvos, dr. Szalai Mária és férje dr. Szíjártó István sümegi háziorvosok, dr. Szabó Tibor OEP főosztályvezető és testvére dr. Szabó Mária radiológiai szakorvos Szombathelyről, dr. Szabó György PhD enesei háziorvos, dr. Ágfalvi Rózsa főorvos asszony, valamint a kiváló egészségfejlesztési képzéseket végző dr. Gritz Arnoldné Budapestről.

Aktív győri kollégáink dr. Tardos Károly, dr. Schneider Károly és dr. Gyarmathy László. Nagy megtiszteltetés volt a szervezóbizottság számára, hogy az Alapellátási Szabadegyetem sikeres megvalósításáért Batthany-Strattmann László dijjban részesült dr. Papp Magdolna és dr. Juhász Julianna győri, dr. Balogh Emil csopaki valamint dr. Decastello Alice PhD Budapest VII. kerületi családorvos. Korompáky Mária fő szervezőnk hasonló tevékenységéért PRO CARITATE díjban részesült.

A határon túlról, a Felvidékről folyamatosan látogatta rendezvényünket MUDr. Czellárik Mária és férje MUDr. Czellárik Sándor, akik fáradságot és időt nem kímélve - Dunaszerdahely, Vágsellye felvidéki településekről érkezve - részletes beszámolókat tartottak a szlovák egészségügyi alapellátásról.

Az Alapellátási Szabadegyetem képzés-továbbképzés rendszere az elmúlt negyedszázad során meszszemenően elérte célját, modellként szolgálhat. Rangos továbbképzéseinket hasonló szellemben szeretnénk folytatni. ${ }^{1,9}$

\section{HIVATKOZÁSOK}

\footnotetext{
${ }^{1}$ Schmidt P. Knausz M. Képzési és továbbképzési modell az egészségügyi alapellátásban: Az Alapellátási Szabadegyetem fennállásának negyedszázados jubileuma ORVOSI HETILAP 156:(22) pp. 907-909. (2015)

${ }^{2}$ Schmidt P. Gazdaságossági kérdések szerepe az egészségügyi alapellátás reformjához kapcsolódóan: Gondolatok az Alapellátási Szabadegyetem 100. rendezvényén ORVOSI HETILAP 145: pp. 355-357. (2004).

${ }^{3}$ Valek A. 2014. évi demográfiai adatok gyermekgyógyászoknak 2014, EGÉSZSÉGFEJLESZTÉS LVII. évfolyam, 2016.1. szám

${ }^{4}$ Schmidt P. Zur Reforms des ungarischen Gesundheitssystems und ihren Auswirkungen. In H-U-Deppe: Zur Aktuellen Entwicklung der Gesundheitspolitik in Ungarn. Arbeitspapier Nr. 15/1995. Klinikum der Johann Wolfgang GoetheUniversitaet, Frankfurt a M. Zentrum der Psychosozialen Grundlagen der Medizin Abteilung für. MEDIZINISCHE SOZIOLOGIE. März 1995, Frankfurt am Main.

${ }^{5}$ Schmidt P. (szerk.) Önkormányzati Háziorvosi Útmutató. Hazánk Könyvkiadó Kft., Győr, 1992.

${ }^{6}$ Schmidt P. A jövő kihívásai az egészségügyi ellátásban, különös tekintettel az egészségmegőrzés és egészségnevelés szempontjaira, valamint az egészségügy gazdasági-közgazdasági kérdéseire In: Tóth Attiláné (szerk.) Tudomány, gazdaság, jövő: Gidai Erzsébet emlékére. Budapest: Arisztotelész Stúdium Bt., 2011. pp. 174-181.

${ }^{7}$ Schmidt P. Az egészségmegőrzés és egészségnevelés meghatározó feltételei és követelményei a jövő sikeres népegészségügyi programjának megvalósításában: Health Education and Health Promotion-Determinativa Conditions and
} 
Requirements for Realising the Public-Health Programme of the Future. GAZDASÁGI ÉLET ÉS TÁRSADALOM 2:(1) pp. 148-156. (2010)

${ }^{8}$ Schmidt P. Az egészségmegőrzés, egészségnevelés szerepe a háziorvosok és egészségügyi dolgozók képzésében, továbbképzésében EGÉSZSÉGNEVELÉS 42:(4) pp. 159-161. (2001)

${ }^{9}$ Menyhárt M. Schmidt P. Konczosné Szombathelyi M. Mester L. Körzeti orvosból háziorvos: 3 évtized tapasztalatai az egészségügyi alapellátás reformját követően: eredmények, tapasztalatok és a jövő kihívásai In: Családorvos Kutatók Országos Szervezete: XVI. Kongresszus - Krónikus betegek gondozása: Szeged, 2017. február 23-25. Konferencia helye, ideje: Szeged, Magyarország, 2017.02.23-2017.02.25. pp. 16-19.

10 Schmidt P. Muzsay G. Akademie der Eltern in Győr. Eine sozialpädiatrische Initiative in der Praxis der Pädiatrie MONATSSCHRIFT KINDERHEILKUNDE 157:(Supl2) pp. 212-213. (2009)

${ }^{11}$ Schmidt P. Fehér J. Egyes preventív lehetőségek a Népegészségügyi Program sikeres megvalósítása érdekében MAGYAR TUDOMÁNY 2007:(9) pp. 1154-1159. (2007)7.)7)

${ }^{12}$ Schmidt P. Meghatározó feltételek és követelmények a jövő sikeres népegészségügyi programjának megvalósításához EGÉSZSÉGFEJLESZTÉS 51:(4) pp. 28-33. (2010)

${ }^{13}$ Gutási É. Alapellátás új minőségben, EGÉSZSÉGFEJLESZTÉS, LVII. évfolyam, 2016. 3. szám 